\title{
PERSPEKTIF POLITIK HUKUM TERHADAP TANTANGAN KEBERADAAN HUKUM MENUJU GLOBALISASI
}

\author{
Oleh : \\ Miftachus Sjuhad*
}

\begin{abstract}
In the field of law, globalization is characterized by the borderless states; no state can claim that it follows a system of law absolutely. There have been mixes and penetration between on system of law to another. In this globalization era, any discussions on the challanges of the existence of law have not been separated from the internal influence of the nation and the surrounding political system and also the cultures. This analyse will explore how the internal and external challenges of the law face the globalization currents that demand on perfect preparation in all aspects.

The political will of the government of Indonesia is really different between before and after the reformation. Multidimensional cries that have not been finished yet may potentially destroy the nation and state of Indonesia up to the zero point. Meanwhile, on the one hand, from the law point of view, in this country, the political products are full of various interests. On the other hand, the national law of Indonesia is facing globalization. Therefore, it is vital to create a harmonious link between the national law and the international law, with attention given to the internal context of Indonesian people.
\end{abstract}

Kata kunci: Politik hokum, Harmonisasi hukum, globalisasi

\section{PENDAHULUAN}

Dunia saat ini mengalami perubahanperubahan yang begitu cepat, sebagai akibat dari ilmu pengetahuan dan teknologi. Manusia bekerja tidak lagi mengandalkan kemampuan ototnya, melainkan sudah memanfaatkan teknologi canggih yang serba otomatis, peralatan elektrik dan sebagainya. Jarak tempat maupun waktu tidak lagi jauh maupun lama. Demikian itu merupaka era industri yang telah mengalami proses kemajuan menuju era baru, yaitu era informasi yang mana hubungan antar manusia sudah tidak lagi dibatasi oleh negara. Nation Without State, inilah yang saat ini akan dihadapi oleh manusia di dunia ini. Inilah yang dinamakan globalisasi.

\footnotetext{
* Dosen Fakultas Hukum Universitas Widyagama Malang
}

Globalisasi, apakah sebuah tantangan ataukah sebuah proses menuju sebuah masa depan? Jawabannya adalah relatif, dalam arti tergantung bagaimana sebuah negara menyikapi. Semangat reformasi pada tanggal 21 Mei 1998 yang lalu, membawa dampak yang cukup signifikan ketika dihadapkan pula dengan proses globalisasi yang ditandai dengan liberalisasi ekonomi tahun 2020 mendatang.

Globalisasi, yang diskenariokan oleh Adam Smith pada tahun 1776, dalam karyanya The Wealth of Nations, mengatakan bahwa persaingan swasta yang bebas dari regulasi, akan menghasilkan produksi dan distribusi

${ }^{1}$ M. Baiquni, 2002, Integrasi Ekonomi dan Ekologi; Dari Mimpi Menjadi Aksi, dalam WACANA, Insist Press, Yogyakarta, hal.21. 
kesejahteraan yang lebih baik daripada pasar yang diatur oleh negara ${ }^{1}$.

Kemudian oleh Alfin Toffler seorang futurolog abad XX, ${ }^{2}$ meramalkan bahwa masa depan ditandai adanya kemajuan pesat di bidang transportasi, komunikasi dan informatika modern merupakan variabel penting yang harus mendapat perhatian dalam pembangunan hukum nasional. Globalisasi mengandung makna yang dalam dan terjadi di segala aspek kehidupan seperti ekonomi, sosial budaya, politik, ilmu pengetahuan dan teknologi, hukum dan sebagainya. Globalisasi yang ditandai dengan revolusi informasi menuntut nilai-nilai dan norma-norma baru dalam kehidupan skala nasional maupun internasional.

Dalam bidang hukum, globalisasi ditandai dengan hilangnya batas-batas kenegaraan (borderless) dan tidak ada lagi negara yang mengklaim bahwa negara tersebut menganut satu sistem hukum secara absolut. Sudah terjadi percampuran dan penetrasi satu sistem hukum ke sistem hukum lainnya. Baik sistem hukum Anglo Saxon, Kontinental, Sosialis maupun sistem hukum Timur Tengan dan Timur Jauh telah saling mengadopsi dan terjadi percampuran hukum. ${ }^{3}$

Pembahasan mengenai tantangan keberadaan hukum di era globalisasi tidak lepas dari pengaruh intern bangsa dalam menghadapinya, sistem politik yang melingkupi maupun budaya masyarakat yang sedang terjadi. Tulisan berikut akan mengemukakan bagaimana tantangan hukum secara intern maupun ekstern dalam menghadapi arus

\footnotetext{
${ }^{2}$ Ahmad Muflih Syaefuddin, 1997, Al-Qur'an : Paradifma IPTEK dan Kehidupan,dalam Mu'jizat AlQur'an dan As-Sunnah tentang IPTEK, Gema Insani Press, Jakarta, hal. 39 ..

${ }^{s}$ Zudan Arif Fakrullah, 2000, Wajah Hukum di Era Reformasi, PT. Citra Aditya Bakti, Bandung, hal. 53.
}

38 I Perspektif Politik Hukum. . globalisasi yang menuntut kesiapan di segala aspeknya. Political will pemerintahan Indonesia sangatlah berbeda antara sebelum dan sesudah reformasi. Krisis multidimensi yang tak kunjung usai sangat mampu untuk menghancurkan bangsa dan negara Indonesia pada titik nol.

\section{PERMASALAHAN}

Persoalan politik hukum menjadi penting ketika masyarakat Indonesia menghadapi berbagai masalah yang di satu sisi berhadapan dengan arus globalisasi di segala aspek dan di sisi lain berhadapan dengan otonomi daerah. Berbagai tantangan menghadang untuk mewujudkan supremasi hukum, antara hukum yang seharusnya (das sollen) -sebagai alasan lahirnya aliran hukum alam- dengan kenyataan (das sein) yang menuntut pendokumentasian hukum dalam hal keberlakuannya -sebagai alasan lahirnya aliran hukum positif-. Berbagai konvensi internasional terlaksana menuju kehidupan global, tantangan besar bagi Indonesia adalah bagaimana mengkondisikan bangsa melalui ratifikasi-ratifikasi hasil konvensi internasional kepada hukum nasional. Melihat kondisi yang berkembang saat ini dengan tetap mengakui bahwa "Hukum merupakan Produk Politik" terdapat perlawanan-perlawanan nilai antara hukum dan politik, dimana hukum menuntut idealnya sebuah aturan, sedangkan politik lebih mengarah pada kompromi-kompromi untuk menegakkan kekuasaan. Namun studi politik hukum memberikan solusi bagaimana mengurangi hegemoni penguasa terhadap hukum yang notabene sebagai alat pemberdayaan masyarakat di hadapan penguasa.

Satu sisi hukum di negeri ini merupakan produk politik yang sarat dengan berbagai kepentingan, di sisi lain hukum nasional Indo- 
nesia terancam dengan globalisme. Secara ringkas, beberapa permasalahan yang menjadi pokok kajian dalam tulisan ini adalah:

1. Bagaimana keberadaan hukum dalam kehidupan politik di Indonesia (masalah internal)?

2. Apa tantangan hukum di era globalisasi (masalah eksternal)?

3. Bagaimana seharusnya wawasan politik hukum dalam rangka pembinaan hukum nasional?

\section{KEBERADAAN HUKUM DALAM KEHIDUPAN POLITIK DI INDONESIA (TANTANGAN INTERNAL)}

Asumsi dasar yang berkembang dalam negara yang menganut paham Trias Politika adalah "Hukum sebagai Produk Politik". Dari asumsi ini kemudian muncul pertanyaan tentang hubungan kausalitas antara hukum dan politik, apakah hukum yang mempengaruhi politik ataukah politik yang mempengaruhi hukum. Maka paling tidak ada tiga macam jawaban, yaitu: ${ }^{4}$

a. Hukum determinan atas politik

Dalam arti bahwa kegiatan-kegiatan politik diatur oleh dan harus tunduk pada aturan-aturan hukum.

b. Politik determinan atas hukum

Hukum merupakan hasil atau kristalisasi dari kehendak-kehendak politik yang saling berinteraksi (bahkan) saling bnersaingan.

c. Keseimbangan derajat determinasi antara Hukum dan politik

Hukum dan politik sebagai subsistem kemasyarakaan berada pada posisi yang derajat determinasinya seimbang antara satu dengan lainnya, karena meskipun hukum merupakan produk keputusan politik tetapi begitu hukum

\footnotetext{
${ }^{4}$ Moh. Mahfud MD, 2001, Politik Hukum di Indonesia, LP3ES, Jakarta, hal. 8
}

ada maka semua kegiatan politik harus tunduk pada aturan-aturan hukum (dalam arti elit politik harus memegang konsekwensi pendapatnya ketika mulai bergesernya interpretasi undang-undang dengan konfigurasi politik yang rawan untuk berubah, pen.)

Di dalam praktek penyelenggaraan pemerintahan, adanya peraturan perundangundangan yang baik akan banyak menunjang penyelenggaraan pemerintahan dan pembangunan sehingga lebih memungkinkan tercapainya tujuan-tujuan negara yang kita inginkan. Sedangkan untuk membuat peraturan perundang-undangan yang baik membutuhkan berbagai kematangan dalam berbagai pengetahuan, mengenai materi muatan yang akan diatur dalam perundang-undangan, dan pengetahuan mengenai bagaimana menuangkan materi muatan tersebut dalam suatu peraturan perundang-undangan secara singkat, jelas, dengan bahasa yang mudah dipahami, sistematis, tanpa meninggalkan tata bahasa yang sesuai dengan kaidah bahasa Indonesia.

Dalam Ilmu Politik pembentukan Undang-undang merupakan bagian dari sekian banyak kebijakan publik, maka dalam ilmu politik hukum dikenal bahwa Legal Policy as Publik Policy. Dengan mempelajari berbagai macam teori pembuatan Undang-undang dalam ilmu hukum (ilmu perundang-undangan) maka perlu juga mempelajari proses pembentukan kebijakan publik yang dibawa oleh pakar ilmu politik.

Secara sederhana, David Easton dalam bukunya A System of Analysis of Political Life memberikan skema sederhana tentang proses terbentuknya sebuah kebijakan publik. Kekuatan-kekuatan yang timbul dari lingkungan dan mempengaruhi sistem politik dipandang sebagai masukan-masukan (inputs) bagi sistem politik, sedangkan hasil-hasil yang dikeluarkan oleh sistem politik yang merupakan 
tanggapan terhadap tuntutan-tuntutan tadi dipandang sebagai keluaran (outputs)..$^{5}$ Lebih jelasnya, maka model sistem politik yang ditawarkan David Easton, akan memberi gambaran dan pemikiran bahwa erat sekali hubungan antara politik dengan hukum terutama dalam proses pembentukan Undangundang.

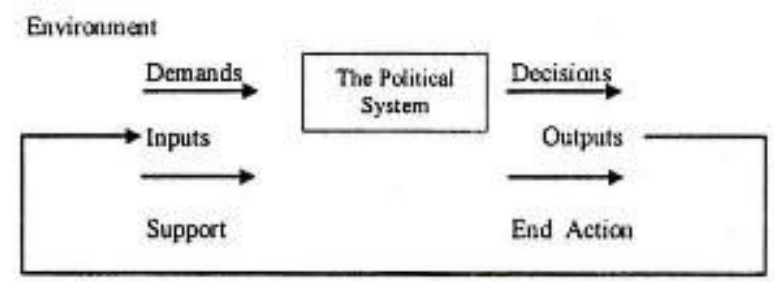

Environment

Environment

\section{Model Sistem Politik ${ }^{6}$}

Dengan demikian proses penyusunan peraturan perundang-undangan yang demokratis sangat ditentukan dan diwarnai oleh struktur masyarakat dan sistem politik suatu negara. Inilah yang dimaksud dengan tantangan intern bangsa yang sedang mengalami proses transisi, satu sisi harus membenahi diri dari beralihnya Orde Baru, dan di sisi lain Indonesia menghadapi arus globalisasi, dimana keberadaan identitas bangsa semakin teruji. Tantangan intern merupakan tantangan yang paling fundamental sebagai pondasi kekuatan bangsa ini.

Keberadaan Hukum Nasional yang semakin menipis identitasnya merupakan imbas dari pengaruh globalisasi. Tantangan besar bagi keberadaan hukum menuju globalisasi semakin tampak ketika globalisasi itu dihadapkan dengan AFTA 2003 apalagi liberalisasi ekonomi 2020 mendatang. Dengan munculnya UU No. 22 Tahun 1999 tentang Otonomi Daerah, berikut UU No. 25 Tahun 1999 Tentang Desentralisasi Fiskal agaknya

${ }^{5}$ Budi Winarno, 2002, Teori dan Proses Kebijakan Publik, Media Pressindo, Yogyakarta, hal. 71.

${ }^{6}$ Esmi Warassih, 2001, Nomor 15 Tahun 4 November, Arena Hukum, Majalah Fakultas Hukum Univesitas Brawijaya, Malang, , hal. 360. semakin memperuncing praktek KKN baik itu di Pemerintah Pusat terlebih Pemerintah Daerah.

Masa depan hukum sangat ditentukan sistem politik, political will dan pola pandang sebuah masyarakat negara. Elemen paling penting yang saat ini mulai ditinggalkan oleh para elit negara adalan Moral Politik, atau tepatnya Moral Elit Politik mulai dari tingkat daerah sebagai pemegang kebijakan kabupaten/kota sampai pada elit politik pusat. Bukan sebuah pekerjaan yang mudah membenahi moral para elit ketimbang memproduk dan memproduk bertumpuktumpuk keputusan yang berupa UndangUndang, Peraturan Daerah dan lain-lain. Tetapi tauladan penegakan materi Undang-Undang, Peraturan Daerah yang dibuat mereka yang menjadi kajian dalam Moral Elit Politik

\section{TANTANGAN KEBERADAAN HUKUM DI ERA GLOBALISASI (TANTANGAN EKSTERNAL)}

Globalisasi ditandai dengan hilangnya batas-batas teritorial kenegaraan (borderless) dan tidak ada lagi negara yang mengklaim bahwa negara tersebut menganut satu sistem hukum secara absolut. Nation Without State, setidaknya menjadi tantangan bagi eksistensi hukum nasional. Mungkinkah hukum akan diberlakukan jika batas ketentuan teritorial sulit tertangani.

Perkembangan seperti itu memunculkan apa yang diajukan oleh Montserrat Guibernau sebagai Nation Without State, yang kemunculannya ditentukan saling hubungan 2 faktor, yaitu semakin intensifnya proses globalisasi dan transformasi yang mempengaruhi the nation-state. Berkaitan dengan hukum suatu negara tidak lagi bertumpu pada pengaturan hukum nasionalnya semata dalam berhubungan dengan bangsa lain 
di dunia, lembaga hukum yang bersifat supranasional sebagai suatu keharusan untuk menjadi hukum nasional. Oleh karena itu pengembangan hukum dengan mengadopsi instrumen-instrumen hukum intenasional yanh berupa traktat-traktat, konvensi-konvensi dan pandangan-pandangan yang bersifat mendunia perlu memperoleh tempat dalam khasanah pemikiran hukum nasional. ${ }^{7}$

Pembahasan mengenai globalisasi memang tidak bisa lepas dengan pembahasan ekonomi (globalisasi ekonomi), globalisasi komunikasi maupun globalisasi informasi yang nantinya juga mempengaruhi terhadap pembentukan hukum nasional. Dilihat dari kacamata sejarah negara-negara industri maju, sesungguhnya di abad 18 telah mulai terjadi internasionalisasi, setelah dalam abad 17 bangsa-bangsa maju sempat menjajah wilayahwilayah seberang lautan dan menjadikan daerah jajahan sebagai pasar baru untuk menjual produk-produk yang dihasilkan, sekaligus juga tempat sumber-sumber bahan mentah untuk diolah di pusat-pusat industri di negaranya masing-masing. ${ }^{8}$

Globalisasi ekonomi pada akhirnya akan membawa dampak kepada globalisasi hukum yang berarti pula masuknya hukum barat yang notabene berlatar kebudayaan barat mengingatkan kita pada penetrasi kebudayaan barat masa Kolonial Belanda. Maka sangat dimungkinkan akan terjadi dominasi antara kebudayaan yang satu dengan kebudayaan yang lain. Yang nantinya akan berkembang kepada penjajahan atas Indonesia yang notabene negara berkembang. ${ }^{9}$ Bedanya untuk saat ini penjajahan intelektual, budaya yang menuju

${ }^{7}$ Supanto, Wajan Hukum di Era Reformasi, hal. 273.

${ }^{\mathrm{s}}$ Sunaryati Hartono, Politik Hukum menuju Satu Sistem Hukum Nasional, Alumni, Bandung, 1991, hal. 66

'Satjipto Raharjo, Hukum dan Perubahan Sosial , Alumni, Bandung, 1983, hal. 101. kepada hukum bahkan ideologi. Masyarakat Indonesia dalam perekonomian dikenal dengan agraris yang ideologinya bertumpu kepada agama mulai hilang sedikit demi sedikit akibat penetrasi dari budaya barat.

Penerimaan ketentuan TRIPs (khususnya), dan hukum yang bersifat internasional (umumnya) akan mempengaruhi terhadap budaya yang berkembang di Indonesia. Jika tidak ditopang dengan sistem hukum yang memadai, maka budaya hukum yang akan terjadi akan semakin kacau.

Berbagai konvensi internasional terlaksana menuju kehidupan global, tantangan besar bagi Indonesia adalah bagaimana mengkondisikan bangsa melalui ratifikasiratifikasi hasil konvensi internasional kepada hukum nasional. Dalam menghadapinya, tentunya para pembuat Undang-undang dalam hal ini legislative harus dapat mempertimbangkan antara hukum peninggalan kolonial yang cenderung liberal-kapitalis dengan jiwa bangsa Indonesia tanpa meninggalkan Global Trends.

\section{WAWASAN POLITIK HUKUM DALAM RANGKA PEMBINAAN HUKUM NASIONAL}

Wawasan politik hukum merupakan doktrin strategis atau strategi dasar dalam mencari rumusan garis politik hukum yang serasi untuk dikembangkan, dengan mempergunakan prinsip-prinsip manajemen strategis khususnya perencanaan strategis.

Tanpa kesiapan, wawasan politik berikut garis politik hukum yang dimaksud, maka sistem perundang-undangan maupun sistem hukum kita akan menjadi "tambal sulam", dan terlalu berbobot pragmatis ketimbang dogmatis dan grounded. Akibatnya, yang dapat dibayangkan, aialah akan lebih banyak kelompok sosial tertentu yang akan mendapatkan pelayanan dan kenikmatan serta 
kemakmuran dari pelayanan hukum itu, ketimbang pemerataan bagi masyarakat pencari keadilan hukum dalam lingkup yang luas, sesuai dengan tuntutan-tuntutan kemanusiaan dan keadilan sosial yang kita anut. ${ }^{10}$

Pembangunan hukum nasional dalam era global dirasakan begitu urgen dengan alasan pertama, bahwa fenomena global yang berkembang di Indonesia tidak dapat dibiarkan begitu saja tanpa aturan. Kedua, hukum merupakan jaminan yang inheren di dalam pembangunan nasional karena hukum sebagaimana dikatakan oleh Parson mampu melekat dalam semua aspek dalam IPOLEKSOSBUDHANKAMNAS. Prof. Muladi dalam makalahnya yang berjudul "Menjamin Kepastian, Penegakan dan Perlindungan Hukum Dalam Era Globalisasi" menyatakan bahwa hukum harus tampil sebagaimana mekanisme pengintegrasi yang dapat mempersatukan berbagai kepentingan, yaitu kepentingan internal bangsa, antara kepentingan nasional dan internasional dan antar sector kehidupan nasional. Ketiga, sebagai norma hukum akan memberikan rambu-rambu dalam tata pergaulan masyarakat sehingga hukum akan menjadi cermin utama kehidupan yang beradab. Keempat, terkait dengan AFTA 2003 dan perdagangan bebas 2020 , hukum akan menjadi bagian yang sangat penting sebagai salah satu wujud jati diri bangsa dalam suasana global yang cenderung liberal."

Sistem hukum nasional yang modern, inilah yang diharapkan bagi negara-negara berkembang di dunia. Menjalankan sistem hukum nasional modern secara optimum akan berhasil jika didukung oleh budaya hukum yang bersumber pada sikap-sikap dan nilai-nilai

\footnotetext{
${ }^{10}$ Solly Lubis, 1995, Bunga Rampai Pembangunan Hukum Indonesia,Editor: Imade Widnyana, PT. ERESCO, Bandung, hal. 5.

"Zudan Arif Fakrullah, hal. 54.
}

seperti kesadaran individu yang tinggi, menolak konflik, ikatan primordial, paternalistik, belum terjadi diferensi sektor publik-privat. Dalam pada itu dengan dijalankannya sistem hukum modern dengan budaya hukum yang mendukung akan menimbulkan suatu jenis praktek hukum khas Indonesia, ${ }^{12}$ Dalam lingkup TRIPs, kondisi seperti itu akan berhadapan dengan universalitas yang telah disepakati negara-negara, sehingga menimbulkan stigma negatif bagi Indonesia perlu dihindari, agar Indonesia tidak dikucilkan dari pergaulan masyararakat global. ${ }^{13}$

Di samping aspek dimensi global, terdapat aspek dimensi domestik. Kenyataan kebhinekaan sosial budaya di Indonesia merupakan kapital sosial. Sehubungan dengan ini, interaksi antara pembangunan hukum pada aras global tidak selalu berjalan mulus apabila dikaitkan pada pembangunan di aras domestik. Inilah salah satu permasalahan besar yang dihadapi. Tuntutan restrukturisasi dalam konteks global diperkirakan akan menimbulkan tekanan-tekanan pada masyarakat di tingkat lokal. Ini sudah kita alami, karena beroperasinya industri-industri modern telah merusak kehidupan lokal Indonesia. ${ }^{14}$

\section{Membangun Paradigma Sistem Hukum Pancasila}

Solusi yang paling harus mendapatkan perhatian besar untuk menghadapi berbagai permasalahan terkait dengan hukum nasional dengan globalisasi adalah tetap tegaknya Volkgeist (menurut aliran Historical School oleh Savigny) bangsa Indonesia yang diimplementasikan ke dalam Pancasila sebagai Grondnorm

\footnotetext{
${ }^{12}$ Satjipto Raharjo, Hukum dan Perubahan Sosial , hal 290

${ }^{13}$ Supanto, Wajah Hukum Di Era Reformasi, hal 285.

${ }^{14}$ Satjipto Raharjo dalam Wajah Hukum Di Era Reformasi, hal 286.
} 
(menurut Kelsen). Pancasila yang merupakan sebuah sistem filasafat sekaligus sistem ideologi Indonesia akan memberi filter sekaligus identitas diri bagi bangsa Indonesia ${ }^{15}$ di tengah arus globalisasi yang menuntut terhapusnya teritorial sebuah negara.

Indonesia yang menyatakan sebagai negara hukum (rechtsstaat), bukan hanya berdasarkan kekuasaan (machtsstaat) belaka, semakin kehilangan identitas diri. Entah karena reformasi yang telah diperbuatnya sendiri ataukah karena arus globalisasi yang semakin menuntut hilangnya batas-batas territorial (borderless). Tetapi apalah artinya menvonis sebuah sejarah yang telah dilukis bangsa ini sendiri, jika tanpa memberi solusi.

Kembali ke nilai-nilai Pancasila-lah sebagai solusi terbaik dan termahal yang saat ini semakin liar dalam menginterpretasikannya. Dalam sejarah perjuangannya, Pancasila sebagai ideologi bangsa yang disepakati sendiri oleh bangsa ini, telah lolos dari berbagai verifikasi ancaman-ancaman ideologi lain, tapi mengapa disintegrasi bangsa, ketidakadilan hukum, dan keliaran liar bangsa ini semakin merajalela? Tulisan ini semoga memberikan arti, yang kurang lebih menyimak dan menghayati kembali ideologi Pancasila.

Global Vision adalah penyatuan visi dalam menghadapi era Nation Without State, yang tidak lain adalah Pancasila. Pancasila merupakan satu-satunya untuk menyatukan Indonesia Masa Depan terutama menghadapi Pasar Bebas 2020. Semakin banyak sejarah yang dilukis bangsa ini, maka semakin teruji bagaimana kesaktian Pancasila selalu ada dalam benak bangsa Indonesia. Dengan

${ }^{13}$ Mohammad Noor Syam, Penjabaran Filsafat Pancasila Dalam Filsafat Hukum (sebagai landasan pemikiran sistem hukum nasional, Laboratorium Pancasila IKIP, Malang, hal. 183. dihapusnya P4 bukan sebuah tantangan bangsa ini untuk menyatukan visi melalui Pancasila.

\section{Harmonisasi Hukum Nasional terhadap Konvensi Internasional}

Pada tahun 2001 yang lalu keluar sebuah TAP MPR RI. No. VII/MPR/2001 tentang Visi Indonesia Masa Depan. Sistematika Pembahasan dalam TAP MPR RI tersebut adalah Bab I tentang Pendahuluan, Bab II tentang Cita-cita Luhur Bangsa Indonesia; Bab III tentang Tantangan Menjelang Tahun 2020, Bab IV tentang Visi Indonesia 2020, Bab V tentang Kaidah Pelaksanaan dan Bab VI Penutup.

Apabila dikaji secara mendalam akan ditemukan pada bab III, bahwa tahun 2020 merupakan tantangan yang bukan hanya harus dihadapi sektor hukum saja, tetapi secara keseluruhan dan saling berkaitan semua sektor yang menentukan masa depan bangsa dan negara Indonesia, yaitu:

1. Pemantapan persatuan bangsa dan kesatuan negara

2. Sistem hukum yang demokratis

3. Sistem politik yang demokratis

4. Sistem ekonomi yang adil dan produktif

5. Sumber daya manusia yang bermutu

6. Sistem Sosial yang beradab

7. Globalisasi

Globalisasi, sebagaimana yang didefinisikan TAP MPR RI. No. VII/MPR/ 2001 tentang Visi Indonesia Masa Depan adalah mempertahankan eksistensi dan integritas bangsa dan negara serta memanfaatkan peluang untuk kemajuan bangsa dan negara. Untuk menghadapinya diperlukan Sumber Daya Manusia dan kelembagaan, baik pemerintah maupun swasta.

Dengan merujuk pada TAP MPR RI. No. VII/MPR/2001 tentang Visi Indonesia Masa Depan tersebut, maka semua ratifikasi -yang 
merupakan konsekwensi dari konvensi internasional- harus sejalan dengan cita-cita luhur yang ada pada ideologi negara yaitu Pancasila. Dengan demikian Mahkamah Konstitusi merupakan lembaga yang paling efisien untuk memberi koreksi maupun kontribusi dalam pembentukan Undangundang melalui Judicial Review dalam rangka menyesuaikan perkembangan Hukum Nasional dengan perkembangan Hukum Internasional.. Setidaknya TAP MPR tersebut merupakan bekal untuk menskenario bagaimana masa depan bangsa.

Harmonisasi atau adaptasi dan yang lebih populer dalam bahasa hukum adalah Ratifikasi, merupakan suatu keharusan bagi negara yang sedang berkembang seperti Indonesia, terutama menghadapi perdagangan bebas 2020 mendatang. Berbagai kesiapan bangsa yang menyangkut Intelektual (Sumber Daya Manusia), Emosional (mental) maupun Spiritual (berkaitan dengan keteguhan bangsa pada Grondnorm) harus disiapkan oleh bangsa Indonesia.

Ratifikasi terhadap konvensi internasional merupakan implementasi dari tujuan Negara Indonesia yang tercantum dalam Pembukaan UUD 1945, yakni ikut serta menciptakan ketertiban dunia. Di samping itu pula secara doktriner diajarkan bahwa traktat internasional merupakan salah satu unsur hukum yang diakui selain undang-undang, yurisprudensi, doktrin dan hukum kebiasaan.

Yang menjadi pegangan mengenai hal ratifikasi perjanjian internasional dewasa ini ialah Konvensi Wina tentang perjanjianperjanjian internasional tahun 1969. Dalam pasal 14 konvensi tersebut diatur cara-cara ratifikasi perjanjian internasional. Pasal 14 ini meyatakan, bahwa negara berhak meratifikasi apabila: ${ }^{16}$

1. Perjanjian tersebut menetapkan demikian

2. Negara-negara yang ikut berunding menyetujui perlu adanya ratifikasi

3. Utusan suatu negara telah menandatangani perjanjian tersebut dengan syarat ratifikasi diperlukan oleh negara yang bersangkutan

4. Full powers delegasi tersebut meyatakan diperlukan adanya ratifikasi atau dinyatakan demikian oleh para utusan selama perundingan berlangsung

Namun harus benar-benar diperhatikan bahwa istilah ratifikasi di dalam Konvensi Wina dipakai dalam arti hukum internasional dan bukan dalam arti Hukum Negara Nasional yang biasanya menentukan perlunya persetujuan lembaga dewan perwakilan atau parlemen, sebelum negara tersebut terikat pada ketentuanketentuan perjanjian internasional. Tentu saja mengenai caranya negara-negara berdaulat mengadakan ratifikasi, dan perjanjian internasional mana yang memerlukan ratifikasi itu ditentukan oleh hukum Tata Negara intern negara-negara. Setiap negara peserta konvensi dapat mengajukan penyempurnaan atau perubahan (amandemen) terhadap ketentuan yang terdapat dalam konvensi.

Pada umumnya tidak semua perjanjian internasional memerlukan ratifikasi, agar perjanjian itu mengikat negara tersebut secara hukum, tetapi perjanjian yang kurang formal sifatnya, tidak memerlukan ratifikasi, seperti pertukaran nota (exchange of notes) dan lainlain perjanjian yang oleh para pihak dimaksudkan segera mengikat setelah ditandatangani (signed) oleh perjanjian tersebut. Dengan demikian hanya perjanjian internasional yang formal yang memerlukan ratifikasi oleh lembaga dan memerlukan

\footnotetext{
${ }^{16}$ Juajir Sumardi, Hukum Ruang Angkasa (Suatu
} Pengantar), Pradnya Paramita, Jakarta, 1996, hal. 70. 
prosedur yang ditentukan oleh Hukum Tata Negara masing-masing peserta. ${ }^{17}$

Yang menjadi pertanyaan, sejauh mana sebuah negara terikat pada perjanjian intenasional tersebut setelah meratifikasi? Hal itu ternyata ditentukan, baik oleh; 1) perjanjian itu sendiri, 2) oleh hukum internasional mengenai perjanjian internasional, antara lain Perjanjian Wina 1969, dan hukum kebiasaan internasional, 3) Hukum Tata Negara yang meratifikasi atau mengadakan akseptasi atau aksesi. Akseptasi (acceptance) merupakan istilah baru yang dapat digunakan dengan dua cara berbeda, yaitu melalui ratifikasi (menurut Hukum Nasional yang bersangkutan), atau melalui aksesi (penandatanganan yang dilakukan oleh suatu negara yang sebelumnya negara yang bersangkutan belum menjadi negara peserta pada saat perjanjian tersebut dinegosiasi), yang tergantung dari rumusan yang digunakan oleh perjanjian internasional yang bersangkutan.

Mengenai Aksesi diatur dala pasal 15 Konvensi Wina 1969 yang menjelaskan, bahwa aksesi dapat dilakukan apabila: ${ }^{18}$

1. Perjanjian internasional itu menyatakan secara tegas

2. Terbukti negara-negara yang turut merundingkan perjanjian tersebut menginginkan demikian

Jadi akseptasi dengan ratifikasi terjadi setelah sebuah negara menjadi peserta, sedangkan aksesi merupakan perjanjian yang sebelumnya sebuah negara belum menjadi peserta dalam melakukan penandatanganan sebuah perjanjian internasional tertentu.

17 Sunaryati Hartono, Ratifikasi Konvensi PBB. Direktorat Jendral Pendidikan Tinggi Departemen Pendidikan Nasional, 2000, hal. 9

${ }^{18}$ Juajir Sumardi, Hukum Ruang Angkasa (Suatu Pengantar), hal 70.
Undang-undang yang meratifikasi suatu perjanjian internasional dapat menggunakan 2 cara: ${ }^{19}$

1. Hanya menyebut secara singkat bahwa konvensi yang disebut namanya dalam Undang-undang yang bersangkutan diratifikasi oleh pemerintah seperti biasanya yang dilaksanakan oleh DPR dan Pemerintah Indonesia, atau

2. Memuat pasal-pasal perjanjian yang diratifikasi

Secara empirik, banyak sekali produk hukum yang dilatarbelakangi oleh arus globalisasi, kesepakatan TRIPs. Produkproduk hukum tersebut sebagian besar merupakan hukum ekonomi terutama pasca reformasi. Antara lain UU No. 5 tahun 1999 tentang Larangan Praktek Monopoli dan Persaingan Usaha Tidak Sehat, UU No 8 tahun 1999 tentang Perlindungan Konsumen. Produk hukum yang berkaitan dengan keamanan muncul juga UU Anti Terorisme, yang berkaitan dengan Otonomi Daerah lahirlah UU No 22 tahun 1999 tentang Pemerintahan Daerah, UU No 25 Tahun 1999 tentang Perimbangan Keuangan antara Pusat dan Daerah.

Sebagian besar produk hukum yang baru di atas belum mampu terlaksana dengan baik, faktor yang paling dominan dikarenakan bangsa Indonesia kurang siap menghadapinya, apalagi dibebani dengan masa transisi dengan tumbangnya Orde Baru. Begitulah akibat dari produk hukum yang tidak muncul dari budaya Indonesia sendiri. Sekali lagi sangat penting untuk menyesuaikan atau mengharmonisasikan antara budaya hukum domestik/lokal Indonesia dengan budaya hukum yang terjadi di dunia internasional. hal 10

t9 Sunaryati Hartono, Ratifikasi Konvensi PBB, Perspektif Politik Hukum . . . 45 


\section{Membangun Moralitas Politik}

Wawasan politik hukum diharapkan bukan hanya mengkaji Intelectual Quotient seorang warga negara secara umum maupun elit politik secara khusus, tetapi menyangkut juga keseimbangan antara Intelectual Quotient, Emotional Quotient dan yang paling puncak adalah Spiritual Quotient. ${ }^{20}$ Kemahiran elit untuk memadukan ketiga kecerdasan tersebut akan semakin terluapkan ketika pembentukan sebuah kebijakan hukum.

Franz Magnis Suseno membedakan perbuatan yang cenderung pada Legalitas dengan Moralitas ${ }^{2 l}$. Saat ini manusia hanya dapat menggunakan legalitas, karena tidak ada perbuatan yang murni moralitas untuk kebenaran, meski manusia selalu dalam proses pencarian Kebenaran. Legalitas merupakan sebuah proses untuk membenahi moral jika diperlukan, sehingga legalitas lebih lanjut hanya sebuah simbol mencari pengakuan di hadapan penguasa.

Dengan tetap menjunjung tinggi nilainilai yang terkandung bagi bangsa dan negara Indonesia, yaitu Pancasila, maka TAPMPR No. VII tentang Visi Indonesia Masa Depan menyatakan bahwa indikator tegaknya keberhasilan bangsa ini adalah: Religius, Demokratis, Adil, Sejahtera, Maju, Penyelenggara Negara yang Baik dan Bersih.

Maka cukup berat kiranya bagi bangsa ini untuk mengkaji wawasan politik hukum yang ideal menuju satu sistem hukum nasional. Berbagai upaya telah dilakukan oleh setiap elemen bangsa ini, bahkan acung jempol buat semua konsep-konsep idealisnya. Namun satu yang paling esensi adalah Integritas Moral bangsa ini yang akan menjawab berbagai

20 (Baca) Ir. Agus Nggermanto Quantum Quotient Kecerdasan Quantum, Nuansa, Bandung, Cet. IV, 2002 tantangan globalisasi. Integritas moral merupakan wujud dari profesionalitas kinerja yang merupakan ciri hukum modern dalam mewujudkan sebuah Sistem Hukum Nasional.

Dengan mempertimbangkan berbagai alasan yang menjadi permasalahan bangsa dalam menghadapi globalisasi terutama menuju sistem hukum nasional adalah: ${ }^{22}$

1. Secara Struktural, diperlukan badan koordinasi pemantauan dan pelaksanaan instrumen-instrumen internasional yang bersifat interdepartemen yang menyangkut unsur suprastruktur, infrastruktur dan kepakaran.

2. Secara Substansial, diperlukan harmonisasi hukum yang cepat dan terencana, antara hukum positif dengan instrumen internasional.

3. Secara Kultural, penyamaan Global Vision dalam menghadapi gelombang globalisasi.

4. Sosialisasi, untuk mengkomunikasikan konvensi internasional yang telah diratifikasi.

\section{PENUTUP}

Dari penjelasan diatas, maka dapat ditarik intisari dari pembahasan, yaitu:

1. Gelombang globalisasi merupakan sebuah konsekwensi yang sesuai rasiologis maupun rasiolegis bagi setiap bangsa, terutama di tengah-tengan komunitas internasional, namun bagaimana sebuah bangsa dapat mempertahankan identitas diri sekaligus jati diri.

2. Indonesia, sebagai Bangsa dan Negara Kesatuan Republik Indonesia adalah salah satu negara berkembang yang ikut berpartisipasi dalam menciptakan ketertiban dunia. Dengan begitu Indonesia tidak dapat menutup diri sebagai negara yang benar-benar murni utuh

\footnotetext{
${ }^{21}$ Franz Magnis Suseno, 2001, hal. 349.

22 Zudan Arif Fakrullah, hal. 58.
} 
menyesuaikan jiwa bangsa, tetapi jiwa bangsa dapat menyesuaikan diri sesuai dengan jati diri dan tuntutan global untuk menunjukkan identitas diri melalui Pancasila.

3. Keberadaan hukum tidak lepas dari proses politik, "Legal Policy as Publik Policy", tetapi harus dilaksanakan dalam kerangka bahwa:

- Cita Politik Nasional adalah terwujudnya Negara Demokrasi: Dari, oleh dan untuk rakyat.

- Cita Hukum Nasional adalah Negara Hukum untuk menjamin kepastian hukum, keadilan dan kemanfaatan

\section{SARAN-SARAN}

1. Integritas Moral, Profesionalitas merupakan rekomendasi yang paling berat untuk dilaksanakan untuk dilaksanakan di setiap elemen bangsa ini, baik melalui Struktural, Substansial, maupun Kultural

2. Untuk menyatukan persepsi dalam menghadapi globalisasi diperlukan sebuah Global Vision yang mengerucut pada satu Grundnorm yakni Pancasila.

3. Dengan bertumpu kepada sebuah ideologi Pancasila yang merupakan jiwa bangsa maka akan terwujud sebuah Sistem Hukum Nasional Indonesia dengan menggali budaya-budaya yang terkandung.

4. Perlu adanya harmonisasi hukum nasional terhadap hukum

$$
-000-
$$

\section{DAFTAR PUSTAKA}

Baiquni, M. 2002, Integrasi Ekonomi dan Ekologi; Dari Mimpi Menjadi Aksi, dalam WACANA, Insist Press, Yogyakarta.

Fakrullah, Zudan Arif. 2000, Wajah Hukum di Era Reformasi, PT. Citra Aditya Bakti, Bandung.

Hartono, Sunaryati. 1991, Politik Hukum menuju Satu Sistem Hukum Nasional, Alumni, Bandung

Hartono, Sunaryati. 2000, Ratifikasi Konvensi PBB. Direktorat Jendral Pendidikan Tinggi Departemen Pendidikan Nasional

Lubis, Solly. 1995, Bunga Rampai Pembangunan Hukum Indonesia, Editor: Imade Widnyana, PT. ERESCO, Bandung.

Mahfud, Moh. MD. 2001, Politik Hukum di Indonesia, LP3ES, Jakarta.

Nggermanto, Agus. 2002, Quantum Quotient Kecerdasan Quantum, Nuansa, Bandung.

Rahardjo, Satjipto. 2000, Pengantar Ilmu Hukum, PT. Citra Aditya Bakti, Bandung.

Raharjo, Satjipto.1983, Hukum dan Perubahan Sosial, Alumni, Bandung

Soeprapto, Maria Farida Indrati. 2002, IImu Perundang-undangan: Dasar-dasar dan Pembentukannya, Kanisius, Yogyakatra.

Sumardi, Juajir. 1996, Hukum Ruang Angkasa (Suatu Pengantar), Pradnya Paramita, Jakarta,

Suseno, Franz Magnis. 2001, Etika Politik: Prinsipprinsip Moral DasarKenegasraan Modern. PT. Gramedian Pustaka Utama, Jakatra.

Syaefuddin, Ahmad Muflih. 1997, Al-Qur'an : Paradifma IPTEK dan Kehidupan, dalam Mu'jizat Al-Qur'an dan As-Sunnah tentang IPTEK, Gema Insani Press, Jakarta.

Syam, Mohammad Noor. Penjabaran Filsafat Pancasila Dalam Filsafat Hukum (sebagai landasan pemikiran sistem hukum nasional, Laboratorium Pancasila IKIP, Malang.

Warassih, Esmi. 2001, Fungsi Cita Hukum dalam Penyusunan Peraturan Perundangundangan dalam Arena Hukum, Majalah Fakultas Hukum Univesitas Brawijaya, 
WIDYH YURIDIKA Jurnal Hukum Volume 1 / Nomor 1 / Juni 2018

Nomor 15 Tahun 4 November, Malang.

Winarno, Budi. 2002, Teori dan Proses Kebijakan

Publik, Media Pressindo, Yogyakarta.

TAP MPR RI. No. VII/MPR/2001 tentang Visi Indonesia Masa Depan.

48 |Perspektif Politik Hukum.. 